\title{
The Importance of Psychosomatic Knowledge for the Treatment Approach in Dermatology
}

The fourth volume of DERMATOLOGY + PSYCHOSOMATICS closes with the present issue and the editors hope to present you a worthwhile selection of psychodermatological publications. The journal intends to communicate a broad spectrum of dermatological topics within a psychosocial context from different parts of the world. We think that the present issue meets our aims.

The importance of psychoneuroimmunological findings in dermatology, mentioned by Schmid-Ott in the last issue [Schmid-Ott, 2003], is stressed by the article of Rabung et al. [2003] which gives an explanation of how psychosocial stressors may influence a skin condition mediated by neuroimmunological pathways. A time series analysis performed in a patient with atopic dermatitis shows both the interaction between psychosocial parameters and skin condition on the one hand, and between skin condition and immunoendocrinological dynamics on the other hand. Thus, only little correlation between immunoendocrinological mechanisms and skin condition was found. The need for further research to elaborate a psychoneuroimmunological model is underlined.

A further case report describes the relevance of psychosocial stressors for another dermatological disease, the basal cell carcinoma. The hypothesis, presented by a Swiss author [Hofer, 2003], that these kinds of stressors can be seen as a cofactor in the etiology of this skin tumor is quite striking as skin tumors are considered to be clinically explained in their pathogenetic pathways. Again, the explanation of this hypothesis lies within the theoretical framework of psychoneuroimmunology. In the presented case, emotional distress due to a body dysmorphic disorder impaired functioning of a suppressor gene which inhibited a self-healing process. The reader may draw his or her own conclusions from the interesting and clinically well-elaborated discussion the author presents.

Besides these contributions which deal with psychosomatics in the sense of explaining the development of a disease, other articles focus on treatment settings including the decision process before psychotherapy as well as the perception of psychotherapic approaches among dermatological subgroups.

An astonishing observation is made by two Australian authors [Hanstock and O'Mahony, 2003] who investigated treatment seeking behavior among patients with acne vulgaris. They found that the more severe acne was, the more non-professional helpers were consulted. Furthermore, less psychopathology was found in those patients who consulted nonmedical professionals but, on the other hand, less acne-related distress was confounded with dermatological treatment.

The question of treatment seeking under the perspective of psychotherapy is posed by Schmidt-Ott et al. [2003], who investigated attitudes towards psychotherapeutic treatment. For this purpose a questionnaire was developed and validated to assess patients' orientation towards psychotherapy. The study shows that psychotherapy is less accepted by dermatological patients than by comparison groups. Thus, in the case of psychodermatological aspects in skin diseases, an extra effort may be necessary to motivate patients for adequate treatment. An inventory may present a useful instrument to screen the patient's way of understanding his or her own disease and treatment.

A case report [Cunha et al., 2003] describes the diagnostic process in a patient with perianal dermatitis and its problems due to the non-compliance of the patient. The dermatological treatment was not continued which may partly be explained by the depression that was diagnosed. Thus, an adequate approach including psychotherapeutic techniques could have been favorable to the patient.

The possible use of psychotherapeutic approaches in a certain group of patients, namely those with a low sense of coherence, is concluded from a study with psoriatic patients [Kupfer et al., 2003]. The authors demonstrate that the time until relapse after inpatient treatment is much longer in those patients with

\begin{tabular}{ll}
\hline KARGER & (c) 2003 S. Karger GmbH, Freiburg \\
Fax +49 761 4520714 & Accessible online at: \\
$\begin{array}{l}\text { E-mail Information@Karger.de } \\
\text { www.karger.com }\end{array}$ & www.karger.com/dps
\end{tabular}

Dr. Ina Zschocke

IFKS - Private Institute for Research Management and Clinical Studies Paula-Modersohn-Platz 3

D-79100 Freiburg

Tel. 49761 45754-11, Fax -29

E-mail zschocke@ifks-biometrie.de 
favorable abilities to cope with the disease than in those with a low manageability of the disease. The sense of coherence seems to be a stronger predictor for the time until relapse after discharge from hospital than the clinical PASI-score.

The editors wish to provide the readers with highly qualified contributions and kindly invite you to participate in the scientific discussion for which DERMATOLOGY + PSYCHOSOMATICS is considered a platform.

\section{Dr. I. Zschocke, Freiburg i.Br.} Editor-in-Chief

\section{References}

Cunha AP, Barros MA, Azevedo F, Resende C: Perianal contact eczema - an unusual presentation of dermatitis artefacta. Dermatol Psychosom 2003;4:219-222.

Hanstock T, O'Mahony JF: Treatment seeking in young women with acne. Dermatol Psychosom 2003;4:194-199.

Hofer T: Reflections on a basal cell carcinoma on the nose of an adolescent monozygotic female twin. Dermatol Psychosom 2003;4:215-218.

Rabung S, Schmidt C, Hüther G, Schauenburg H: The influence of psychosocial stressors on neuroimmunological parameters and skin conditions in a patien with atopic dermatitis. Dermatol Psychosom 2003;4:207-214.

Schmid-Ott G: Future trends in psychodermatological psoriasis research: Somatopsychic or psychosomatic focus? Dermatol Psychosom 2003;4:129-130.

Schmid-Ott G, Reibold S, Ernst G, Niederauer HH, Künsebeck HW, Schulz W, Lamprecht F, Jäger B: Development of a questionnaire to assess attitudes towards psychotherapeutic treatment. Dermatol Psychosom 2003;4:187-193. 